not the press should expose and deal with blatant drug peddling and indiscriminate abortionist activities.

The present resistance to the annual fee is surely only a symptom of frustration at a body out of touch with the bedside. It should not be beyond the wit of the B.M.A. to persuade the G.M.C. to disclose its activities and expenses and in return support an appropriate annual fee. If both sides remain obdurate we will all lose. A large section of the profession will soon be debarred from practising and the Government will have to intervene. A temporary Register (inevitably to become permanent) will be compiled, doctors will continue to practise, and the G.M.C. will become defunct or suffer a ministerial takeover. Shortsighted doctors wil chortle over their victory while the State assumes total control over the profession. Never will so much have been surrendered for a fiver.

It sickens me to see the lengths to which the profession is prepared to go against a section of itself. If this intransigent stance had been adopted on more important fronts we might not have had two successive $\mathrm{Re}$ view Body awards reduced (the loss of which would more than have paid G.M.C. fees for life), a pension scheme still woefully wanting and a Government contract for consultants and general practitioners that would make a solicitor gasp. The B.M.A. subscription is $£ 21$; that of the medical defence societ:es $£ 25$, and the G.M.C. retention fee has been pitched at $£ 5$. These are all realistic figures. What is absurd is the doctors' earning capacity in this country under the N.H.S. Sir Keith Joseph must be watching our present internal dispute with amusement and amazement but certainly with no anxiety. We could scarcely be affronted if he felt he could run our affairs more adroitly. We may overwhelm the G.M.C. only to find we were concentrating on the wrong tanget-I am, etc.,

Chorleywood, Herts

J. M. LAURENT

\section{Abortion Deaths}

SIR,-Dr. Josephine A. C. Weatherall (21 October, p. 176) suggests that Sir George Godber's comments on abortion deaths, in the preface to the Report of Confidential Enquiries into Maternal Deaths in England and Wales 1967-69,1 were in part prompted by "knowledge of the complete figures." $\mathrm{He}$ himself said, however, "This inquiry is the only available, reliable source of information about this particular aspect of the working of the Abortion Act."

Like Professor H. C. McLaren (30 September, p. 826), I serve as a regional assesso in relation to the confidential inquiry and, like him, I find Sir George's use of the word "improvement" in the preface impossible to equate with the facts in the report. This is particularly unfortunate, as the preface is the part of such reports most widely quoted in the press and elsewhere.

The harsh statistic is that in 1967, the last year before the introduction of the Abortion Act in 1968, and in 1969, the first year after, the number of deaths due to induced abortion were precisely the same. In 1967 only $3 \%$ were associated with "legal" abortion, whereas in $196941 \%$ were associated with "legal" abortions. This shift was achieved by performing over 1,000 abortions for every week of 1969 . This might be regarded as "improvement" from the point of view of the load on the judiciary but certainly not from a medical angle. Had Sir George called for immediate repeal of the Abortion Act it would have been understandable: that he could produce a complacent statement is rather frightening.

We hear much these days about accountability in the health service of the future. The Confidential Enquiry on Maternal Mortality was a model of what can be achieved from critical analysis of clinical care with the co-operation of a team of clinicians, and Sir George in his own preface to the report says the inquiry "should be an incentive to those in other fields of medicine who are prepared to undertake the selfdiscipline of this kind of retrospective inquiry into the results of their work. . . . It is to be hoped that other comparable exercises will become part of the Health Service in future." Sir George's hopes will be realized only if his successors resist the temptation to cloak unfavourable statistics which may emerge. Otherwise clinicians will not be prepared to give their time and effort. -I am, etc.,

Department of Obstetrics and Gynaecology,

University of Leeds

1 Report of Confidential Enquiries into Maternal Deaths in England and Wales 1967-69. Reports on Health and Social Subjects, No. 6. London,

SIR,-Mrs. Madeleine Simms is quite right (21 October, p. 176): in 1968 the Chief Medical Officer did indeed comment in his annual report ${ }^{1}$ that for 1967 both abortion deaths at 34 and non-abortion maternal deaths at 140 looked "exceptionally low" by comparison with 53 and 169 in 1966 and probably also taking into account the 1968 figures. which were up again to 50 and 150 respectively. But he would hardly wish to stand by that comment now, since in 1969 non-abortion deaths were even lower at 120 and 114 in 1970, with abortion deaths given as 35 and 32 for those two years.

Maternal mortality has been falling very satisfactorily over the past 20 years and more, but until recently the non-abortion mortality was being reduced proportionately more than for deaths resulting from abortion, as the following figures will show:

Maternal Deaths (England and Wales)

\begin{tabular}{cc|c|c}
\hline \multicolumn{2}{c|}{ Year } & Abortion & Non-Abortion \\
\cline { 1 - 1 } 1950 &. & 103 & 517 \\
1955 & $\because$ & 66 & 382 \\
1960 & $\because$ & 62 & 548 \\
1965 & $\because$ & 52 & 169 \\
1970 &. & 32 & 114
\end{tabular}

From 1967 onwards, however, the reductions in recorded abortion deaths seem to have been catching up. But whatever the reason for this it can hardly be regarded as a consequence of the Abortion Act, which did not come into operation until 27 April 1968.-I am, etc.,

Gonville and Caius College,

C. B. GOODHART Cambridge

1 Department of Health and Social Security, On the State of the Public Health. 3968, Annual Report of the Chief Medical
Barbiturates in Pregnancy

SIR,-In my time as orthopaedic surgeon at Harrow and Watford I came across perhaps a dozen cases of typical carpal tunnel syndrome arising in the last three months of pregnancy and causing much loss of sleep from the usual mixture of pain, tingling, and numbness in one or both hands. Two of these young women were the wives of orthopaedic registrars, who had tried the usual conservative measures such as injections of hydrocortisone into the flexor tendon sheaths at the wrist and a plaster night splint. Some of the others were taking so much sedative that they felt drowsy for most of the day and incapable of caring for a baby properly. All of them were screened for early toxaemia; only one was so affected, and she was whisked away by an obstetrician harbouring the baseless notion that all incisions in the palm develop keloid.

For all the remainder I performed complete open division of the transverse ligament strictly in the midline (continuing the line of the tendon of palmaris longus) under local anaesthesia, using the safe dose of $10 \mathrm{ml}$ plain lignocaine $1 \%$ and an arm-cuff to control haemorrhage. This is a simple outpatient procedure, which should not take more than five minutes from first prick of the needle and inflation of the cuff to the last of the half-dozen sutures required to close the short incision across the butt of the palm. One woman came back to have the other side done a fortnight later. All the patients were truly grateful for the rapid relief given.

This brings me to your leading article (14 October, p. 64) on disturbed neonatal behaviour in 15 infants born to mothers taking barbiturates throughout pregnancy or in its last trimester. Two of the four mothers who had taken the barbiturates as sedatives, not because of addiction or epilepsy, were "apprehensive and deeply fatigued." For me those words ring a bell.-I am, etc.,

KARL NISSEN

Sherborne, Dorset

Rh Isoimmunization in Ruptured Pregnancy

SIR,-The paper by Drs. J. Katz and R. G. Marcus on the risk of $R h$ isoimmunization in ruptured tubal pregnancy (16 September, p. 667) prompts me to comment.

The authors cite as the only evidence of fetomaternal haemorrhage the demonstration of acid-resistant cells in the maternal circulation. That these cells could be of maternal and not fetal origin is a possibility dismissed in the report with the contradictory statements "The incidence of hereditary persistence of the fetal haemoglobin gene in the South African Bantu has been estimated to be of the order of 1 in 1,000." and "There is therefore no evidence of an increased incidence of high levels of fetal haemoglobin in the local African population. If anything the incidence is possibly less than in other population groups. ..." This particular circumstance apart, raised levels of $\mathrm{Hb} \mathrm{F}$ are characteristic of sickle-cell anaemia and some of the thalassaemia syndromes. I have encountered grand multiparity in an African homozygous for $\mathrm{Hb} \mathrm{S}$, and contrary to the apparent belief of Drs. Katz and Marcus thalassaemia is recorded as occurring in 